\title{
KAP study of contraception in clients undergoing MTP and sterilization in Gujarat, India
}

\author{
Rakesh Patel*, Runoo Ghosh
}

Department of Obstetrics and Gynecology, GMERS Medical College, Gandhinagar, Gujarat, India

Received: 31 March 2017

Accepted: 27 April 2017

\section{*Correspondence:}

Dr. Rakesh Patel,

E-mail: drrakesh_patel@yahoo.in

Copyright: ( $)$ the author(s), publisher and licensee Medip Academy. This is an open-access article distributed under the terms of the Creative Commons Attribution Non-Commercial License, which permits unrestricted non-commercial use, distribution, and reproduction in any medium, provided the original work is properly cited.

\begin{abstract}
Background: Lack of awareness, knowledge and education, religious beliefs and fear of side effects are the main causes why women do not use family planning methods. To study the knowledge, attitude and practice of contraception among clients undergoing to Medical termination of pregnancy (MTP) and sterilization.

Methods: This prospective study was done among 400 indoor cases at Department of Obstetrics and Gynecology in B.J. Medical college, Ahmedabad during July 2002 to October 2003. All the clients undergoing MTP and sterilization were explained and counseled about contraception with GATHER approach of family planning. After taking detail history, a thorough clinical examination of the clients was carried out with preliminary investigations.

Results: Almost 58\% clients were willing to accept TL method as contraceptive option, 39.5\% IUCD, 1.75\% OC pill method of contraception. Regarding history of side effect of contraceptive use, $17.3 \%$ condom users, $68.5 \%$ OC pill users, $63 \%$ CuT users have felt side effect. Almost $42.5 \%$ clients were operated by MTP + Lap TL, 39.5\% by MTP + CuT and $14.5 \%$ by plain Lap TL.

Conclusions: Efforts should be made to promote information, education and communication regarding emergency contraception targeted to all women of reproductive age group. It is important that unwanted pregnancy be prevented through effective contraceptive practice rather than abortion.
\end{abstract}

Keywords: Condom, Contraceptive, MTP, OC pills

\section{INTRODUCTION}

India is the second most populous country in the world and has a rapidly growing population where 16 million people are added per year. ${ }^{1}$ To slow down this growth rate, the National Population Policy was revised by the Government of India in 2000, with the objective of bringing down the total fertility rate to the replacement level by $2010 .{ }^{1}$ Unmet need still remains same in spite of the government's constant efforts. ${ }^{2}$

In spite of increased use of contraceptive, almost $50 \%$ pregnancies are unplanned and almost $60 \%$ pregnancies result in abortion. Lack of awareness, knowledge and education, religious beliefs and fear of side effects are the main causes why women do not use family planning methods. ${ }^{3}$

In 1971, Government of India has passed Medical Termination of Pregnancy Act to legalize the medical termination of pregnancy and to reduce the maternal morbidity and mortality associated with illegal abortions. ${ }^{1}$ Abortion has become a common method of limiting and spacing birth, but it should on no account be promoted as a family planning method. High rates of induced abortions reflect low prevalence of contraceptive use and its effectiveness. ${ }^{3}$

This study was conducted with the objectives of studying the knowledge, attitude and practice of contraception 
among clients undergoing to Medical termination of pregnancy (MTP) and sterilization.

\section{METHODS}

This prospective study was done among 400 indoor cases at Department of Obstetrics and Gynecology in B.J. Medical college, Ahmedabad during July 2002 to October 2003. Data collection done after ethical permission from institutional ethical committee and informed consent of clients.

All the clients undergoing MTP and sterilization were explained and counseled about contraception with GATHER approach of family planning. After taking detail history, a thorough clinical examination of the clients was carried out with preliminary investigations like Hemoglobin estimation, urine albumin and sugar examination. Related investigations like urine pregnancy test, Trans-vaginal sonography, ABORh was done as per requirement.

\section{Statistical analysis}

Statistical Test Data was collected and entered in Microsoft Excel Sheet and analyzed by Epi.info version 7. For continuous variables range, mean and standard deviation has been calculated and for categorical variables proportion and percentage has been obtained. To know the association between dependent and independent variable chi-square has been applied accordingly. $\mathrm{P}$ value less than 0.05 will be considered as statistically significant.

\section{RESULTS}

Table 1 shows that highest number of clients $(56.75 \%)$ were belongs to age group of 26-30 years. Almost $94.75 \%$ clients were from urban area and $5.25 \%$ from rural area. MTP with temporary contraceptive method was performed in $43.25 \%$ among study clients.

Table 1: Socio-demographic characteristics $(\mathrm{N}=400)$.

\begin{tabular}{|l|l|}
\hline Variable & Number (\%) \\
\hline Age Group & \\
\hline $15-20$ & $5(1.25)$ \\
\hline $21-25$ & $109(27.25)$ \\
\hline $26-30$ & $227(56.75)$ \\
\hline $31-35$ & $50(12.5)$ \\
\hline Residence & $379(94.75)$ \\
\hline Urban & $21(5.25)$ \\
\hline Rural & \\
\hline Type of procedure & $1(0.25)$ \\
\hline Only MTP & $168(42.0)$ \\
\hline MTP with temporary contraception & $173(43.25)$ \\
\hline MTP with sterilization & $58(14.5)$ \\
\hline Only sterilization & \\
\hline
\end{tabular}

Table 2: Knowledge, attitude and practice regarding contraception.

\begin{tabular}{|c|c|}
\hline Variable & Number $(\%)$ \\
\hline \multicolumn{2}{|c|}{ MTP with temporary contraception $(n=169)$} \\
\hline Primi & $71(42.01)$ \\
\hline Second & $89(52.66)$ \\
\hline Third & $9(5.33)$ \\
\hline Multi & $0(0.0)$ \\
\hline \multicolumn{2}{|c|}{ MTP with sterilization $(\mathrm{n}=\mathbf{2 3 1})$} \\
\hline Primi & $2(0.86)$ \\
\hline Second & $116(50.22)$ \\
\hline Third & $69(29.87)$ \\
\hline Multi & $44(19.05)$ \\
\hline \multicolumn{2}{|c|}{ History use of contraception $(n=400)$} \\
\hline User & $322(80.5)$ \\
\hline Non-user & $78(19.5)$ \\
\hline \multicolumn{2}{|c|}{ History of contraceptive use $(n=322)$} \\
\hline Condom & $295(91.61)$ \\
\hline OC pill & $111(34.47)$ \\
\hline $\mathrm{CuT}$ & $89(27.63)$ \\
\hline Inj DMPA & $10(3.1)$ \\
\hline Emergency contraception & $1(0.31)$ \\
\hline \multicolumn{2}{|c|}{ Awareness of contraceptive method $(n=400)$} \\
\hline Natural method & $235(58.75)$ \\
\hline Condom & $367(91.75)$ \\
\hline $\mathrm{CuT}$ & $338(84.5)$ \\
\hline OC pill' & $316(79.0)$ \\
\hline Inj DMPA & $105(26.25)$ \\
\hline Emergency contraception & $9(2.25)$ \\
\hline Sterilization & $367(91.75)$ \\
\hline No knowledge & $33(8.25)$ \\
\hline \multicolumn{2}{|c|}{ Willingness of use of contraceptive method $(n=400)$} \\
\hline Tubal ligation & $231(57.75)$ \\
\hline IUCD & $158(39.5)$ \\
\hline OC pill' & $7(1.75)$ \\
\hline Inj DMPA & $3(0.75)$ \\
\hline Only MTP & $1(0.25)$ \\
\hline Condom & $0(0.0)$ \\
\hline \multicolumn{2}{|c|}{ Side effect of previously use of contraceptive method } \\
\hline Condom & $51 / 295(17.30)$ \\
\hline OC pill & $76 / 111(68.5)$ \\
\hline $\mathrm{CuT}$ & $56 / 89(62.95)$ \\
\hline Inj. DMPA & $7 / 10(70.0)$ \\
\hline \multicolumn{2}{|c|}{ Incidence of failure of contraception $(n=400)$} \\
\hline Condom & $7(2.37)$ \\
\hline OC pill & $0(0.0)$ \\
\hline IUCD & $2(2.24)$ \\
\hline Inj. DMPA & $0(0.0)$ \\
\hline Tubal Ligation & $1(0.25)$ \\
\hline \multicolumn{2}{|c|}{ Contraceptive method performed $(n=400)$} \\
\hline MTP+Lap TL & $170(42.5)$ \\
\hline $\mathrm{MTP}+\mathrm{CuT}$ & $158(39.5)$ \\
\hline Plain Lap TL & $58(14.5)$ \\
\hline $\mathrm{MTP}+\mathrm{OC}$ pill & $7(1.75)$ \\
\hline MTP+inj. DMPA & $3(0.75)$ \\
\hline $\mathrm{MTP}+\mathrm{Abd} \mathrm{TL}$ & $3(0.75)$ \\
\hline MTP only & $1(0.25)$ \\
\hline
\end{tabular}


Table 2 shows that $42 \%$ primigravida clients were operated for MTP with temporary contraception. Almost all multipara clients were operated for MTP with sterilization.

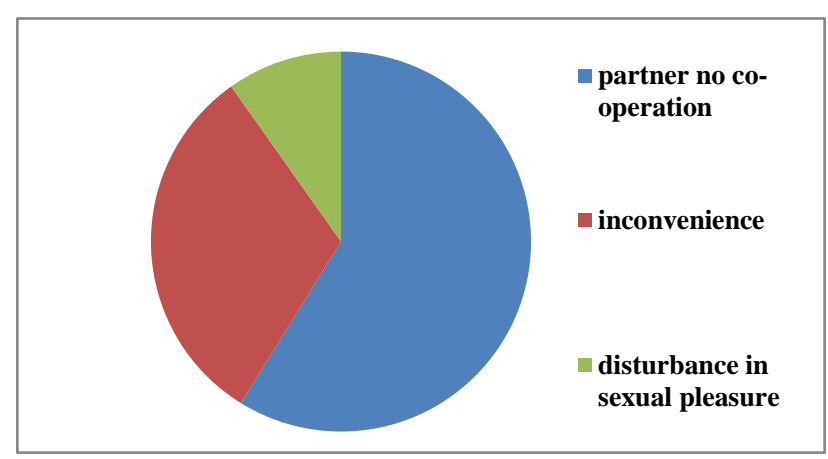

Figure 1: Side effect of use of condom.

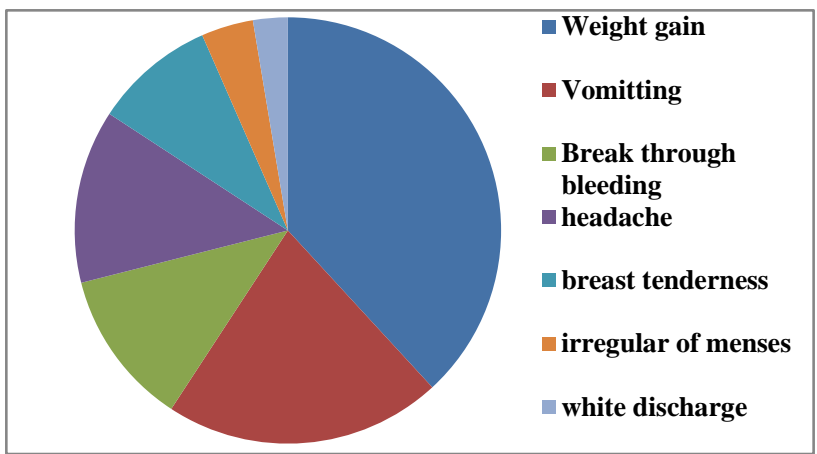

Figure 2: Side effect of use of $\mathrm{OC}$ pill.

Almost $20 \%$ clients had history of no use of contraception. Out of 322 clients who had history of use of contraception, $91 \%$ used condom, $35 \%$ OC pill, $28 \%$ copper-T and only $3 \%$ used Inj. DMPA.

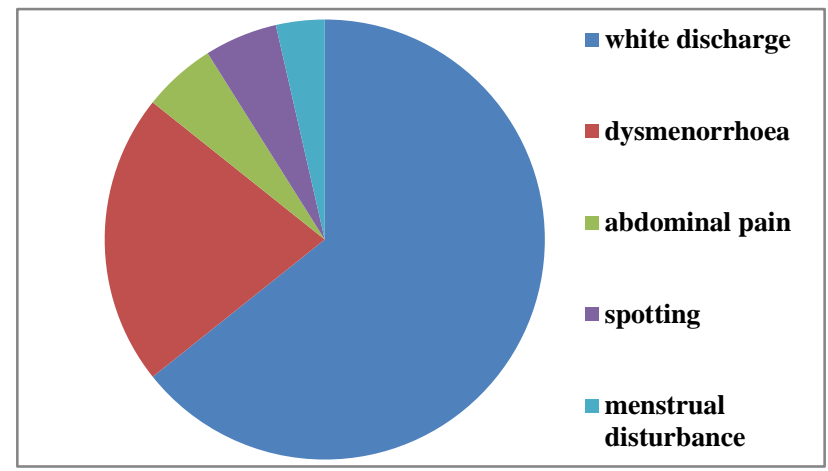

Figure 3: Side effect of IUCD.

Almost 59\% clients were aware about natural methods of contraception, $92 \%$ of condom, $84.5 \%$ of $\mathrm{CuT}$ and $79 \%$ OC pill method of contraception. Almost $58 \%$ clients were willing to accept TL method as contraceptive option, $39.5 \%$ IUCD, $1.75 \%$ OC pill method of contraception. Regarding history of side effect of contraceptive use, $17.3 \%$ condom users, $68.5 \%$ OC pill users, 63\% CuT users have felt side effect. Almost 42.5\% clients were operated by MTP+Lap TL, $39.5 \%$ by $\mathrm{MTP}+\mathrm{CuT}$ and $14.5 \%$ by plain Lap TL.

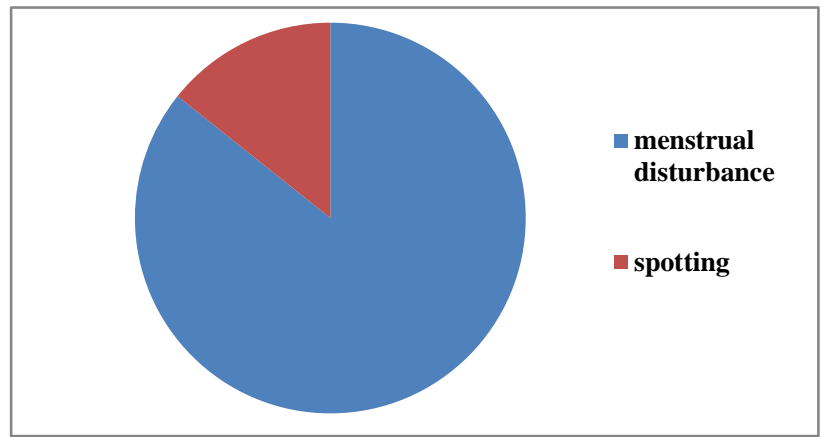

Figure 4: Side effect of inj. DMPA.

\section{DISCUSSION}

India was the first country in the world to implement a National Family Planning Programme in $1952 .{ }^{4}$ There are a variety of methods of regular contraception which are available for the individual choice of a woman, which include natural methods, barrier methods, oral pills, intrauterine devices, progesteron injections and permanent methods in the form of female and male sterilizations. $^{2}$

In present study, non-use of a contraceptive at the time of conception is low (19.5\%) as compared to that in the study by Young et al (39\%), by Aneblom et al (33\%) and Srivastava $\mathrm{R}$ et al (55.2\%). ${ }^{1,3,5}$ The highest awareness in our study was for condom (92\%) and female sterilization $(92 \%)$ followed by awareness for other methods like CuT $(84.5 \%)$, OC pill $(79 \%)$ and almost negligible awareness found for emergency contraception $(2.25 \%)$. These findings are consistent with results of similar study done by Srivastav $\mathrm{R}$ et al and Bhat PV et al. ${ }^{1,3}$ and not consistent with results of similar study done by Bromham DR et al and Young et al. 5,6

Present study found that $0.8 \%$ primi para, $50 \%$ second para and $30 \%$ third para clients want MTP with sterilization. Similar study done by Bhat PV et al. ${ }^{3}$ found that $14 \%$ primi para, $80 \%$ second para and $5.1 \%$ third para clients wanted MTP with sterilization. This study observed that previously used contraception method was 92\% condom, 34\% OC pill, $28 \% \mathrm{CuT}$ and $3 \%$ Inj. DMPA. Study done by Bhat PV et al. ${ }^{3}$ observed this was $39 \%$ condom, $23 \%$ natural method, $19 \% \mathrm{CuT}, 7 \%$ OC pill and $1 \%$ Inj. DMPA.

\section{CONCLUSION}

Study results shows that $20 \%$ clients were not using any contraceptive methods and awareness of emergency contraceptive method was very low. Misconceptions and misinterpretation regarding use of various contraceptive methods are still present in community. Efforts should be 
made to promote information, education and communication regarding emergency contraception targeted to all women of reproductive age group. It is important that unwanted pregnancy be prevented through effective contraceptive practice rather than abortion. And it's also important that regular availability of contraceptives and adequate health care services at the peripheral level should be available. This can be done by collective efforts of political system, government, private sector, NGOs and community.

Funding: No funding sources Conflict of interest: None declared

Ethical approval: The study was approved by the Institutional Ethics Committee

\section{REFERENCES}

1. Reena S, Kumar SD, Radha J, Kumkum S, Neela S, Sushmita S. Contraceptive knowledge attitude and practice (KAP) survey. J Obstet Gynecol India. 2005;55(6):546-50.

2. Umashankar KM, Dharmavijaya MN, Jayanta Kumar DE, Kala K, Nagure AG, Ramadevi. Survey of the attitude to, the knowledge and the practice of contraception and medical abortion in women who attended a family planning clinic. J Clin Diagnostic Res. 2013;7(3):493-5.

3. Upadhyay UD, Brown BA, Sokoloff A, Raine TR. Contraceptive discontinuation and repeat unintended pregnancy within 1 year after an abortion. Contraception. 2012;85(1):56-62.

4. Aneblom G, Larsson M, Odlind V, Tydén T. Knowledge, use and attitudes towards emergency contraceptive pills among Swedish women presenting for induced abortion. BJOG An Int J Obstet Gynaecol. 2002;109(2):155-60.

5. Young LK, Farquhar CM, McCowan LM, Roberts HE, Taylor J. The contraceptive practices of women seeking termination of pregnancy in an Auckland clinic. New Zealand Med J. 1994;107:189-92.

6. Bromham DR, Cartmill RS. Knowledge and use of secondary contraception among patients requesting termination of pregnancy. Br Med J. 1993;306:556.

Cite this article as: Patel R, Ghosh R. KAP study of contraception in clients undergoing MTP and sterilization in Gujarat, India. Int J Reprod Contracept Obstet Gynecol 2017;6:2503-6. 